\title{
Baseline characteristics are not sufficient indicators of non-response bias in follow up studies
}

\author{
Jørgen Vestbo, Finn Vejlø Rasmussen
}

\begin{abstract}
Study objective-The aim was to examine whether baseline characteristics from a cross sectional survey provided sufficient information regarding non-response bias in a follow up study when compared with information on hospital admissions in the intervening years.

Design-This was an 11 year follow up study of a cohort selected in 1974 with register information on hospital admissions during follow up.
\end{abstract}

Setting-The study was based on a sample of cement workers from a particular Portland cement factory with suitable controls from other occupations.

Participants-A total of 1404 men participated in the first survey in 1974, including a questionnaire and lung function tests. In 19851070 men were alive and of these, 928 men $(87 \%)$ responded to a postal questionnaire.

Main results-Non-responders in 1985 did not differ markedly from responders when smoking habits, respiratory symptoms, and lung function were examined in 1974. During follow up, non-responders had twice as high rates of hospital admission due to respiratory diseases as responders. These differences remained present after adjusting for minor differences in age and smoking habits.

Conclusions-Equal distributions of baseline characteristics among responders and non-responders in a follow up study do not preclude non-response bias.

f Epidemiol Community Health 1992; 46: 617-619

Non-response in epidemiological surveys is a well known source of selection bias. ${ }^{1}$ Several approaches using alternative information on nonresponders in postal questionnaire surveys have been used, often showing marked differences in both population characteristics and indirect health measurements. Generally, poor response is associated with advancing age, low educational level, semi-skilled or unskilled manual occupations, and poorer health status, although examples of the opposite can easily be found..$^{2-7}$

Baseline information can be used to elucidate differences between responders and nonresponders in follow up studies. No studies have been published comparing baseline information with alternative information on disease in the intervening years. In general, few studies have been published using alternative information about sickness/sickness absence during follow up. ${ }^{2} 45$
We decided to examine whether baseline information provided sufficient information on differences between responders and nonresponders in a later follow up when compared with information on hospital admissions in the intervening years.

\section{Methods}

In 1974-75 a total of 1404 men aged 46-69 years was examined with interview and lung function tests. The main purpose of the study was to assess the effects of inhaled cement dust on lung function. Results of the study have been published earlier. ${ }^{8}$

All men were interviewed using the British Medical Research Council (BMRC) questionnaire on respiratory symptoms ${ }^{9}$ together with questions on smoking habits, occupational, and residential histories. Cough was recorded if the subject answered affirmatively to either of the two BMRC questions on cough, and phlegm was recorded similarly. Chronic bronchitis was recorded if the subject reported cough and phlegm lasting three months or more for at least two years. Men who smoked more than $10 \mathrm{~g}$ of tobacco daily in 1974 were classified as heavy smokers whereas men smoking $10 \mathrm{~g}$ or less were classified as light smokers. Men who had spent most of their working life in a particular Portland cement factory were classified as cement workers; the others were classified as blue collar workers, white collar workers, or others according to the occupational category in which they had spent most of their working life.

Spirometry was performed using a Godart Expirograph type 16000 (Bilthoven, Holland); all indices were reported at BTPS as mean value of three measurements. A chest $x$ ray with anteroposterior and left lateral projection was done in all subjects.

According to the Danish National Board of Health, 334 of the men in the study had died by 27 October 1985. On 3 November 1985 all living members of the cohort received a postal questionnaire containing 41 questions and a post-paid envelope for the return of the questionnaire. Two reminders were sent to initial non-responders after intervals of two to three weeks.

Information on hospital admissions was obtained from the National Patient Register which is a nationwide register of all admissions to somatic hospital wards. The register was established in 1977 and is administered by the Danish National Board of Health. In this study, only admissions of $24 \mathrm{~h}$ duration or more were included. Hospital admissions were registered in two periods: from 1 January 1977 to 31 October 1985 , and from 1 November 1985 to 3 September 1986. 
Causes of admission were classified using the WHO International classification of diseases, 8th revision. ${ }^{10}$ They were divided into admissions due to respiratory disease in general (ICD 460519) and admissions due to chronic obstructive pulmonary disease (COPD, ICD $492-493$ or 519).

\section{Results}

The response rate at follow up was $87 \%$. The distributions of population characteristics, smoking habits, respiratory symptoms, and spirometric measurements in 1974 for responders, nonresponders, and non-survivors are shown in table I. No significant differences were found between responders and non-responders. When com-

Table I Baseline characteristics in 1974 for responders, non-responders, and nonsurvivors in the cohort.

\begin{tabular}{|c|c|c|c|}
\hline & $\begin{array}{l}\text { Responders } \\
\text { (928 men) }\end{array}$ & $\begin{array}{l}\text { Non- } \\
\text { responders } \\
(142 \text { men })\end{array}$ & $\begin{array}{l}\text { Non- } \\
\text { survivors } \\
(334 \text { men })\end{array}$ \\
\hline $\begin{array}{l}\text { Mean age (years) } \\
\text { Heavy smokers ( } \%) \\
\text { Cement workers (\%) } \\
\text { Blue collar workers }(\%) \\
\text { Cough ( } \%) \\
\text { Phlegm (\%) } \\
\text { Dyspnoea grade } 3 \text { or worse }(\%) \\
\text { Dyspnoea grade } 4 \text { or worse }(\%) \\
\text { Chronic bronchitis ( } \%) \\
\text { FEV } 1 \text { (mean, litres) } \\
\text { FVC (mean, litres) } \\
\text { FEV (mean) for men with dyspnoea grade } 3 \\
\text { or worse (litres) } \\
\text { FEV (mean) for men with dyspnoea grade } 4 \\
\text { or worse (litres) }\end{array}$ & $\begin{array}{c}55 \cdot 1 \\
46 \cdot 1 \\
21 \cdot 0 \\
38 \cdot 8 \\
26 \cdot 5 \\
20 \cdot 4 \\
13 \cdot 0 \\
6 \cdot 3 \\
9 \cdot 2 \\
3 \cdot 06 \\
4 \cdot 22\end{array}$ & $\begin{array}{c}56 \cdot 1 \\
52 \cdot 8 \\
16 \cdot 9 \\
48 \cdot 6 \\
31 \cdot 7 \\
21 \cdot 1 \\
15 \cdot 1 \\
7 \cdot 2 \\
8 \cdot 5 \\
2 \cdot 95 \\
4 \cdot 13\end{array}$ & $\begin{array}{l}57 \cdot 3 \\
58 \cdot 4 \dagger \\
17 \cdot 4 \\
43 \cdot 4 \\
34 \cdot 1^{\star} \\
26 \cdot 6^{\star} \\
20 \cdot 3 \dagger \\
14 \cdot 2 \dagger \\
11 \cdot 4 \\
2 \cdot 65 \\
3 \cdot 81\end{array}$ \\
\hline
\end{tabular}

$\mathrm{FEV}_{1}=$ Forced expiratory volume in $1 \mathrm{~s} ; \mathrm{FVC}=$ Forced vital capacity

${ }^{\star} \mathrm{p}<0.05, \mathrm{tp}<0.005 v$ responders $\left(\chi^{2}\right.$ test $)$

paring $\mathrm{FEV}_{1}$ values in the same breathlessness category, both non-responders and non-survivors tended to have lower values than responders. No differences between responders and nonresponders were found concerning cardiac enlargement on the $x$ ray or symptoms of heart disease. In the period $1977-85$ a total of 46 responders $(5.0 \%)$ and 14 non-responders $(9.9 \%)$ had been admitted to hospital because of respiratory disease in general. Of these, a total of 25 responders $(2.7 \%)$ and nine non-responders $(6.3 \%)$ had been admitted because of chronic obstructive pulmonary disease $\left(p<0.05, \chi^{2}\right.$ test)

For the purpose of adjusting for minor differences in baseline characteristics between responders and non-responders, multivariate logistic regression analyses with the two categories of hospital admission as dependent variables and age and smoking habits in 1974 as covariates were performed. Non-response was entered as an independent variable. Results are given in table II; odds ratios (OR) and 95\% confidence intervals (CI) are shown. Nonresponse was significantly related to hospital admission both in general and due to chronic

Table II Determinants of hospital admission due to respiratory disease in general and admissions due to chronic obstructive pulmonary disease (COPD) estimated using multivariate logistic regression analyses.

\begin{tabular}{|c|c|c|}
\hline Variable & $\begin{array}{l}\text { Hospital admission due } \\
\text { to respiratory disease } \\
\text { (Odds ratios with } 95 \% \text { CI) }\end{array}$ & $\begin{array}{l}\text { Hospital admissions } \\
\text { due to COPD } \\
\text { (Odds ratios with } 95 \% \text { CI) }\end{array}$ \\
\hline $\begin{array}{l}\text { Age (per } 10 \text { years) } \\
\text { Light smokers }{ }^{a}{ }^{a} \\
\text { Heavy smokers }^{a}\end{array}$ & $\begin{array}{l}1 \cdot 2(0 \cdot 8-1 \cdot 8) \\
1 \cdot 1(0 \cdot 5-2 \cdot 5) \\
1 \cdot 6(0 \cdot 8-3 \cdot 1)\end{array}$ & $\begin{array}{l}1.5(0 \cdot 8-2 \cdot 6) \\
1.4(0 \cdot 4-4 \cdot 7) \\
3.0(1 \cdot 1-7 \cdot 9)\end{array}$ \\
\hline Non-response & $2 \cdot 0(1 \cdot 1-3 \cdot 8)$ & $2 \cdot 2(1.0-4 \cdot 9)$ \\
\hline
\end{tabular}

${ }^{a}$ In contrast to never smokers and ex-smoker

$95 \% \mathrm{CI}=95 \%$ confidence interval obstructive pulmonary disease, $\mathrm{OR}=2 \cdot 0(95 \%$ CI $1 \cdot 1-3 \cdot 8)$ and $O R=2 \cdot 2(1 \cdot 0-4 \cdot 9)$, respectively, after controlling for age and smoking habits.

In the 10 month period following the questionnaire survey two non-responders $(1.4 \%)$ and four responders $(0.4 \%)$ were admitted to hospital because of respiratory disease in general. Both the non-responders, but only one responder, were admitted because of chronic obstructive lung disease.

\section{Discussion}

Non-response is a threat to both cross sectional surveys and follow up studies. In a hypothetical study, Greenland has stressed that risk ratios from studies with non-response evenly distributed with respect to the exposure or the outcome can be altered due to non-response. ${ }^{11}$ Although this could also be the case when comparing baseline information among responders and nonresponders in a follow up, such comparisons are made in epidemiological studies of respiratory disease. ${ }^{12}{ }^{13}$ This is probably due both to the lack of other ways of estimating the effect of nonresponse and to the fact that baseline information is often readily available. In other studies the association between non-response and physical health status has not been overwhelming. Trent and Ames, ${ }^{14}$ summarising earlier studies on nonresponse, found no consistent relationship between participation and objective measures of health status whereas several studies have found an association between self reported symptoms and participation..$^{15-17}$

We found an increased number of admissions to hospital due to respiratory disease in general and chronic obstructive lung disease among nonresponders when comparing with responders. Similarly, Cobb et al ${ }^{4}$ found a threefold increase in the proportion of men who had had three or more hospital admissions in the preceding five years. Our register data on hospital admissions were obtained from the Danish National Patient Register which was started in 1977 for administrative purposes. For this reason information regarding number of admissions, duration, and registration of ward/hospital is accurate. The validity of the diagnosis in the register is probably more dubious, as pointed out by Jürgensen $\mathrm{et} \mathrm{al} .^{18}$ Some overlap between respiratory diseases and, for example, cardiovascular diseases is bound to occur but is not ruinous to this study.

It is interesting that the 142 men who are characterised by their non-response in a follow up survey and who have experienced more hospital admissions are roughly comparable with responders when looking at respiratory symptoms at the time of the initial survey. A marked underrating of symptoms among later nonresponders could explain the seemingly equal prevalences of respiratory symptoms. We have tried to evaluate this by looking at $\mathrm{FEV}_{1}$ values among responders and non-responders with the same grade of breathlessness. Our results, shown in the lower part of table I, only provide very limited support for this hypothesis and cannot solely explain our findings.

In conclusion, equal distributions of baseline characteristics among responders and non- 
responders in a follow up study do not preclude non-response bias.

This study was supported by grants from The Danish Medical Research Council (12-5877) and The Knud Høigaard Foundation (7818).

1 Alderson M. An introduction to epidemiology. London: Macmillan, 1976

Sheikh K. Predicting risk among non-respondents in prospective studies. Eur $\mathcal{F}$ Epidemiol 1986; 2: 39-43.

3 Jooste PL, Yach D, Steenkamp HJ, Botha JL, Rossouw JE. Drop-out and newcomer bias in a community cardioDrop-out and newcomer bias in a community cardio-
vascular follow-up study. Int $\Im$ Epidemiol 1990; 19: 284-9. 4 cobbular follow-up study. Int $\mathcal{F}$ Epidemiol 1990; 19: 284-9. and nonrespondents in a morbidity survey involving clinical examination. $\mathcal{F}$ Chron Dis $1957 ; 6$ : 95-108.

5 Bergstrand R, Vedin A, Wilhelmsson C, Wilhelmsen L. Bias due to non-participation and heterogeneous sub-groups in population surveys. $\mathcal{F}$ Chron Dis 1983; 36: 715-8.

6 Sonne-Holm S, Sørensen TI, Jensen G, Schnohr P. Influence of fatness, intelligence, education, and sociodemographic factors on response rate in a health survey. $\mathcal{F}$ Epidemiol Community Health 1989; 43: 369-74

7 Bakke P, Gulsvik A, Lilleng P, Overå O, Hanoa R, Eide GE. Postal survey on airborne occupational exposure and respiratory disorders in Norway: causes and consequences of non-response. F Epidemiol Community Health 1990; 44 316-20.
8 Rasmussen FV, Borchsenius L, Holstein B, Sølvsteen P. Lung function and long-term exposure to cement dust. Scand $\mathcal{F}$ Resp Dis 1977; 58: 252-64.

9 Medical Research Council's committee on the aetiology of chronic bronchitis. Standardized questionnaires on respiratory symptoms. BMF 1960; ii: 1665.

10 World Health Organization. International classification of diseases, 8th revision. Geneva: WHO, 1977.

11 Greenland S. Response and follow-up bias in cohort studies. Am 7 Epidemiol 1977; 106: 184-7.

12 Beck GJ, Doyle CA, Schachter EN. A longitudinal study of respiratory health in a rural community. Am Rev Respir Dis 1982; 125: 375-81.

13 Olofson J, Bake B, Svärdsudd K, Skoogh B-E. The single breath $\mathrm{N}_{2}$-test predicts the rate of decline in $\mathrm{FEV}_{1}$. The study of men born in 1913 and 1923. Eur $\mathcal{F}$ Respir Dis 1986; 69: $46-56$.

14 Trent RB, Ames RG. Respiratory health as a predictor of questionnaire return in a sample of United States underquestionnaire return in a sample of United States unde

15 Abramson JH, Kark SL, Epstein LM, Hopp C, Peritz E Makler A. A community health study in Jerusalem. Isr $\mathcal{f}$ Med Sci 1979; 15: 725-31.

6 Forthofer RN. Investigation of nonresponse in NHANES II. Am $\mathcal{f}$ Epidemiol 1983; 117: 507-15.

17 Wiley JA. Camacho TC. Life-style and future health: Evidence from the Alameda County Study. Prev Med 1980; 9: $1-21$.

18 Jürgensen HJ, Frølund C, Gustafsen J, Mosbech H Guldhammer B, Mosbech J. Registration of diagnoses in the Danish National Registry of Patients. Methods Inf Med 1986; 25: 158-64. 